\title{
Factors and 'illusions' influencing the choice of PFI-type Public Private Partnerships
}

\section{PRE-PROOF VERSION}

\section{To cite this document:}

\author{
Ronald McQuaid, (2019) "Factors and "illusions" influencing the choice \\ of PFI-type public private partnerships", World Journal of \\ Entrepreneurship, Management and Sustainable Development, \\ https://doi.org/10.1108/WJEMSD-07-2018-0066
}

\section{Ronald McQuaid, Stirling Management School, University of Stirling, UK}

\begin{abstract}
Purpose: This paper critically assesses some of the micro- and macro-economic reasons for using Public Finance Initiative (PFI) types of Public Private Partnerships (PPPs) and how a lack of transparency may result in an 'illusion' of making optimal, rational decisions related to them. A series of balances that decision makers need to make in order to choose whether or not to use PPPs are set out, as well as 15 potential 'illusions' that may affect such decisions.
\end{abstract}

Design/methodology/approach: The paper synthesizes public evidence and develops a framework for the analysis of PPPs.

Findings: A wide range of factors influence the choice of PPPs, including: budget enlargement; efficiency and value for money; certainty of expenditure and delivery; flexibility; financing costs; risk sharing; procurement process and transaction costs; legacy and public assets; and the wider impacts on the local economy. However, reasons why PPPs can provide improved infrastructure and services may not be realised due to in-built incentives, behavioural biases and implementation shortcomings. Necessary support for PPPs includes strong, robust and transparent regulatory and governance systems, the dissemination of good practice to all partners, consideration of alternative funding models and high quality advice and training.

Research implications: The paper sets out a number of reasons for using PPPs, but also assesses potential drawbacks and identifies areas where greater research is required. A number of potential 'illusions' are identified, whereby decisions may be affected by factors not explicitly or transparently considered, hence giving the decision an 'illusion' being rational.

Practical implications: PPPs are significantly influenced by the socio-economic, legal, legislative and financial system they are embedded in. A clear process for approving projects and recognising all the costs and benefits of PPPs is needed, including developing criteria and instruments to measure each phase of a PPP and its overall value added to the economy and society over its lifetime. Full transparency, having suitable support and explicitly taking account of potential 'illusions' affecting decisions could lead to different decisions, including the decision not to progress the project or to use alternative funding and development methods. 
Social implications: Decisions on PPPs should be based on a clear and transparent longterm basis which includes the perspectives of the full range of stakeholders to help improve the appropriate operation and social sustainability of a PPP.

Originality/value: The paper sets out some key arguments for and against the used of PPPs in different circumstances, including why non-optimal decisions may be made.

Keywords: Public Private Partnerships, PPP, Private Finance Initiative, PFI, rational decisions

Type of Paper: Research paper

\section{Introduction}

Public Finance Initiative (PFI) types of Public-Private Partnerships (PPPs) have become a relatively popular way of providing public infrastructure and services across the world, and their use is supported by many international and national bodies (e.g. European Commission, 2012; OECD, 2012a, b; UN, 2011; World Bank, 2015; Bull, 2010). PPPs can be used to help provide services as well as the infrastructure, but the consequences of doing so need careful consideration. Major reasons cited for using PFI-types of PPPs include: introducing greater innovation, efficiency and effectiveness (mainly through introducing private sector techniques and inputs and greater competition) and enlarging public budgets in the short-term by bringing in private financing. Other broad reasons for the greater use of PPPs include: changing perceptions of the role of the public sector from being a provider of infrastructure and services to being an enabler and, usually, funder of them; using outcomes as measures of public service provision success rather than outputs or inputs measures; and shifting some public budgets towards the private sector.

Although PPPs have been used for millennia, in recent decades the UK has been seen as one of the major early adopters of PFI type PPPs ${ }^{1}$. This is where the private sector funds upfront costs in return for a long-term payment, accounting for around $10 \%$ of public infrastructure (OECD, 2014, p.14). The use of PPPs has declined in the UK in recent years, arguably due to improved transparency, questions about value for money, inflexibility, austerity and changing accounting standards removing an accounting advantage of PPPs in terms of them now counting as part of the national debt. This means that the high payments for existing PPPs will gradually decline until around 2028-9, and afterwards decline more rapidly until around 2050 (HM Treasury, 2016a, b).

\footnotetext{
1 The term PPP can also be used for more voluntary, less contractually, based 'partnerships', which are more concerned with a partnership between stakeholders. For example the ILO (2008, p.1, building on UN, 2001) describe them as 'voluntary and collaborative relationships among various actors in both public (State) and private (non-State) sectors, in which all participants agree to work together to achieve a common goal or undertake specific tasks. Partnerships may serve various purposes, including advancing a cause, to implement normative standards or codes of conduct, or to share and coordinate resources and expertise'. However, while these are very important (McQuaid, 2000, 2010), the current paper only focuses upon PFI-type PPPs.
} 
Internationally, based on a variety of sources, Inderst (2016) estimate that total global volumes of PPPs have been around US $\$ 60-\$ 100$ billion in recent years (about $0.1 \%$ of GDP). Across much of Europe (especially Italy, UK and France and Turkey) (EPEC, 2018), and in North America there has be considerable infrastructure provision and services based PPPs although Asia is well below the global average.

The use of PPPs may also be influenced to some degree by bringing concepts from New Public Management (NPM) into public sector management (McQuaid, 2010). Although NPM may be in decline (Dunleavy et al., 2006), it remains to be seen if new forms of public and network governance influence future PPPs. Under PFI-type PPPs, the public sector still has democratic accountability and responsibility for defining the service (or infrastructure characteristics) and choosing between the objectives, therefore seeking to ensure that the wider public interest is taken fully into account (McQuaid and Scherrer, 2010, p.29). It also decides on monitoring and standards of delivery, with performance measures, with effectiveness usually measured in terms of outputs, service quality measures, efficiency, financial performance and process and activity measures (OECD, 2008).

When considering the introduction of PPPs to social services, there is a need to recognise the increasing complexity of services and infrastructure and the changing nature of public services. These include the multi-dimensional set of factors that affect service users and the services they need, such as individuals' health, housing, childcare, local demand, social networks as well as skills, etc. Hence often a multi-agency \&/or multi-service response, with a range of resources and expertise, is required. This leads to questions of how best to coordinate them? Are PPPs likely to be more or less efficient and effective in the long-term? In addition many welfare services are concentrated among disadvantaged groups and areas so how locally and community responsive are PPPs likely to be? With increasing, persistent demands for social services (e.g. demographic change leading to more requirements for services for the elderly), some argue that many countries are moving from a welfare state towards a welfare services state, where many services will no longer be provided primarily by the state (e.g. Bifulco, 2016). If so, is co-ordination of services carried out through intraPPP/consortium mechanisms by contractual PPPs more efficient and effective than other forms of public-private intra-organisation co-ordination or by public provision, and what types of PPPs may or may not be appropriate for providing such services? Are contractual PFItype PPP relationship better than other forms of delivery or partnership (e.g. with NGOs)?

The answers are likely to depend on specific services or infrastructure, circumstances, types of partnership and types of partners. However, in seeking to shed light on these questions, there is often an assumption of rationality underpinning decisions on PPPs. As argued below 
many decisions on PPPs may in practice be subject to factors that can lead to deviations from rational choices ${ }^{2}$. Hence, while the reasons for choosing PPPs may seem rational, the actual basis of the choice may be influenced by various non-rational factors and 'illusions'.

The remainder of the paper presents a brief outline of PPP definitions and then goes on to assess various arguments for the use of PPPs, and how and why some of these may not be realised. These broad overlapping factors are discussed in terms of: budget enlargement; efficiency and value for money; certainty of expenditure and delivery; flexibility; financing costs; risk sharing; procurement process and transaction costs; legacy and public assets; and the wider impacts of PPP on the local economy. The paper then briefly considers a series of balances that a decision maker needs to make in order to choose whether or not to use PPPs, especially services based ones, and if so what type of PPP to use. Some 15 'illusions' are summarised before the conclusions are presented.

\section{Definitions of PPP}

There is no universal definition of PPPs (examples include: Hodge and Greve, 2013; OECD, 2008, pp.15-17; UN, 2011). There are several definitions used by international organisations related to contractual, PFI-type, PPPs. The OECD (2014) states that:

'Public-Private Partnerships (PPPs) are long term contractual arrangements between the government and a private partner whereby the latter delivers and funds public services using a capital asset, sharing the associated risks.'

Services are explicitly included in the World Bank's (2014) definition of a PPP as a:

'long-term contract between a private party and a government agency, for providing a public asset or service, in which the private party bears significant risk and management responsibility' (World Bank, 2014, p.17).

Similarly the European Commission's (2004) Green paper on PPPs terms them:

'forms of cooperation between public authorities and the world of business which aim to ensure the funding, construction, renovation, management or maintenance of an infrastructure or the provision of a service'.

Contractual PPPs involve: the private provision of infrastructure and/or services that are usually provided by the public sector for the common good, and therefore involve some continued public sector involvement; mainly private sector investment, but usually funded

\footnotetext{
2 Rational choices are considered here to be where a decision-maker accurately evaluates the optimal outcome between choices, given the information available (see Eisenführ, et al., 2010).
} 
over the long term by the public sector (or sometimes also by users); the sharing of substantial risks (financial, technological and operation) related to the project's design, build, operation or financing; long-term projects and contracts; and are output rather than input focused (see for example, Malone, 2005).

\section{Reasons for the choice of PPPs and associated 'illusions'}

The choice of whether to use a PPP (instead of other options such as the more traditional public financing mechanisms), and if so which type of PPP to use, is based on a range of factors. Major arguments for the use of PPPs often relate to micro-economic issues as they are seen to: increase innovation, effectiveness and efficiency when providing public infrastructure and services; increase choice and quality of public services; and improve the equality of social services between different geographical areas (such as urban-rural) (see for example: Thieriot and Dominguez, 2015; NHS Executive, 2004). PPPs also present more macro-economic opportunities for governments to access greater private finance and to 'spend today and pay tomorrow' (so-called 'budget enlargement'). They can also provide opportunities for private and NGO bodies to access major new income streams and markets, formerly reserved for public sector providers (McQuaid and Scherrer, 2010). The European Commission (2004) identified four main private sector roles in PPPs, the first about access to finance, and the others generally about improving delivery: providing additional capital; providing alternative skills in management and implementation; adding value to both the consumer and the general public; and identifying needs and the optimal use of resources.

Given these broad potential arguments in favour of using PPPs, there are a number of critical success factors which increase the likelihood of all parties having a positive outcome. These should influence the types and characteristics of PPPs chosen and how they are implemented and include: managing risks effectively; providing services or infrastructure of appropriate quality that fully meets specifications on time; reliable and high quality service provision; effective partnership working and long-term relations; value for money; efficient contracting and procurement processes; and (for the private sector) profitable provision (e.g. Martin et al., 2013; Osei-Kyei et al., 2017). In addition, for welfare and other services especially, incorporating the views and needs of service users and local communities, as well as other stakeholders, is crucial. The paper now discusses the various potential reasons for the use of PPPs in service and infrastructure provision.

\section{Budget Enlargement}


PPPs have often been presented as a means of enlarging the effective public sector budget over the short-term (e.g. UNECE, 2008, 2012; McQuaid and Scherrer, 2010), through keeping much of the capital costs of PPPs 'off balance sheet' (e.g. not showing the full extent of the liability for the capital expenditure or commitment in the government accounts). The OECD (2011) found that this was more important than value for money in some countries, while the Dutch Policy and Operations Evaluation Department (IOB), (2013) found that most PPPs were for budget enlargement (additional financial mobilisation) reasons rather than for improved effectiveness. This tends to be more important for projects that are primarily about physical infrastructure provision, but can affect services where there is a need for considerable capital outlay (e.g. for new or modified premises or equipment).

International accounting standards have changed in the last decade, so more expenditure must be shown 'on balance sheet', particularly where there is only a limited transfer of risk (McQuaid and Scherrer, 2010; House of Lords, 2010). The effects of these standards (e.g. Financial Reporting Advisory Board (FRAB), 2007) are sometimes unclear as they may depend on the exact interpretation by national and international bodies. If their rules are fully applied then this should lead to PPPs being compared more accurately to other procurement methods. Interestingly, a potential change from the former UK PFI to the revised Private Finance 2 (PF2) system is that the public sector no longer paid for the project's capital costs over the construction period, but rather over the life of the project (HM Treasury, 2016b). This may mean that costs are spread out over a longer period than under previous regulations, requiring them to be included when paid, which may support suggestions that previous methods of accounting were influenced by budget enlargement. In the UK, the National Audit Office (2018, p. 10) stated that most PFI debt is scored as 'off-balance sheet' for national account purposes, under the European system of accounts (ESA) that determines government debt levels, while according to International Financial Reporting Standards (IFRS), which are used to produce government financial accounts, most PFI debt is 'onbalance sheet'.

Budget enlargement is especially attractive when there are major infrastructure needs. PPPs can allow official public debt to be kept lower than under 'traditional' procurement, and so improve the government's position in international financial markets, or to meet debt limits on public borrowing. In addition, overall tax burdens in the medium term might be reduced if PPPs are more cost-effective than traditional public procurement. However, the reverse is possible if the PPPs are less efficient overall in practice. The evidence on the effects of PPPs on public finances is mixed (Hodge and Greve, 2007). If previously sheltered sectors undergo deregulation and economic structural change, then PPPs may raise efficiency 
(McQuaid and Scherrer, 2010, p.30). However, private borrowing costs are almost invariably higher than those of the public sector and there are usually high fees (perhaps 1-2\% of total PPP/PFI payments) (National Audit Office, 2018). So the efficiency gains from PPPs need to at least compensate for the extra financial and transaction costs that they incur, otherwise the budget financing leads to a 'fiscal illusion' where the financial burden of PPPs is spread out over many years and is not seen immediately in public budgets. Therefore, it is essential that PPPs are adequately monitored and the true levels of risk, capital and revenue liabilities are shown in a way consistent with international accounting standards. Without clear and transparent public accounts for PPPs, it is difficult to determine if PPPs increase or decrease the long-term tax and debt burden.

Budget enlargement may also occur during the implementation of a PPP. For instance, PPPs have sometimes been used to realise the value of land or other assets (e.g. where public land is part of the PPP 'package') and so raise public expenditure. Some UK local authorities have generated land value by building schools on Greenbelt land and houses on former school sites (so allowing high housing land values to be realised). Planning permission might not have been given to building houses directly on the Greenbelt but would be given for a school, so this might mean that local planning regulations could potentially be influenced by the PPP (McQuaid and Scherrer, 2010).

\section{Efficiency and value for money}

Micro-economic PPP factors focus on the potential for improving the efficiency, effectiveness and value for money of projects. It may do this through the introduction of new (largely private sector) skills and practices, incentives and innovation, together with potential economies of scale and scope, and more efficient utilisation of assets and 'cradle-to-grave' or whole life asset management (European Commission, 2004; NHS Executive, 2004; HM Treasury, 2000, 2008; World Bank, 2009).

A further reason for improved efficiency is the introduction of greater competition for, and the contestability of, the PPP. However, experience suggests that sometimes competition in PPPs can been limited, partly as economies of scale may limit competition to larger firms, technical and financial resources may restrict the numbers of firms able to bid, and PPPs are usually put forward by consortia (hence several potential competitors may be working together, reducing competition overall). PPPs generally have low numbers of bidders, therefore reducing the real level of competition and its potential benefits, due in part to the monopolistic-type or oligopolistic behaviour by the firms. In addition, under 'traditional' procurement there is often considerable competition (e.g. when tenders are requested to build, or design and build, infrastructure). In this way, the specific benefits of PPPs are 
affected by the way in which competition is introduced. However, compared to a purely public sector delivered project, rather than traditional procurement using outside (non-public sector) contractors, there is likely to be greater competition.

Hoppe et al. (2010) suggest that, while PPP type contracts should have greater incentives for cost reductions than using a single contractor, quality might go up or down. Current public operations may include additional services that are not explicitly set out in the contract - and so these will no longer be provided by the PPP. It is useful if such extra services (e.g. special treatment for those with disabilities) are made explicit and so are properly funded; in practice, however, this may not be the case.

Factors that may negatively affect PPP development and implementation include differing value and ethical systems of the public and private sector actors (OECD, 2008), poor design of contracts and inappropriate risk sharing, and a lack of accountability (Pollock et al., 2007; Pollock and Price, 2013). In terms of value for money, Barlow et al. (2013) argue that results for healthcare PPPs in the European Union, across different forms of financing and PPPs, have been mixed, and accommodation only PPPs (e.g. building and maintaining hospitals) have not seen the expected cost savings. The National Audit Office (2018) and Treasury Committee Treasury Committee (2011, p. 48) found, respectively, that efficiencies often failed to materialise with, for instance, schools costing $40 \%$ higher than if funded by government borrowings and hospitals $70 \%$ more expensive that the public sector comparator. Meanwhile, Torchia et al. (2015) found that while PPPs have been used to address internationally emerging public health issues, their effectiveness, efficiency and convenience are unclear.

The balance between partners is important for achieving value for money. The basic legal framework, including state laws, influences the degree of favour towards the private sector partners, and this appears to be affected by economic and political circumstances, such as general economic growth, congestion and need for infrastructure and political composition in the legislature (see Geddes and Wagner, 2013, for US examples).

In the early UK PFI/PPPs, there were a number of cases of excessive, windfall profits for private partners and hence reduced public income. The UK House of Commons Public Accounts Committee (2011, p.3) review argued that PFIs (Private Finance Initiative types of PPP) had been a better deal for private investors than the taxpayer. Similarly, there was a UK review of $\mathrm{PFI}$ in 2012 with changes made to the $\mathrm{PFI}$ model so as to improve transparency, value for money and partnership working (PF2) (HM Treasury, 2012; National Audit Office, 2009; Reynaers and Grimmelikhuijsen, 2015). 
Hence, the OECD (2012a) and others argue strongly for clear consideration of value for money in PPPs. The IoB (2013) found that evaluations tended to focus on resource sharing, while the issues of risk sharing and revenue distribution in PPPs received little attention in half of the selected studies. Most goals were quite general (e.g. improved co-ordination) and few were output specific. Although most of the small number of PPPs reviewed had positive outputs, it was usually unclear if these were attributable to the PPP, and most evaluations were not particularly robust scientifically (e.g. scoring lowly on the Maryland Scale of Scientific Methods). Therefore, the conclusion is clear - few PPP evaluations were based on rigorous and robust impact analysis, and the case for the value for money of PPPs is uncertain- an 'evaluation illusion'.

\section{Certainty of expenditure and delivery}

In general, public sector expenditure flows have greater certainty under PPPs. This is partly due to costs (with an added inflation element) generally being agreed over the entire life of the project, with the developer usually taking the risk of cost overruns or increased costs above some agreed level, or of lower income than expected.

However, there may be considerable difficulties in changing a PPP contract after it is signed (e.g. specifications or design features are difficult to change, while views on how services should be delivered also change over time). Other types of procurement (such as 'traditional' public borrowing and managed methods) may incorporate greater temptation and scope for the project's public sector commissioner to change specifications at a late stage or during its development, often incurring large additional costs. PPPs usually therefore introduce greater discipline to the public sector, although this discipline could be achieved through better project planning, procurement and management among project commissioners after signing the initial contract.

PPPs may also restrict the decision maker's ability to alter or merge infrastructure as these are set out for decades in the contract. An example is if a group of social service facilities (e.g. schools) are to be amalgamated. The PPP funded ones are likely to be kept open if circumstances change as it is harder and more expensive to close them, even if it would have been preferred to have kept the non-PPP facilities open instead. This can lead to the potential inefficient location of services in the long-term. So there may be an 'illusion of flexibility' with PFI-type PPPs.

There are normally strong incentives for the private partner to complete PPP projects on time, as added costs or delay penalties can be incorporated into the contract. In some cases payments may not start until after completion of construction, giving incentives especially 
where the developer has high initial financing costs. The agreement of, for instance, a design and build PPP may include streamlined land assembly, planning and other agreements, so reducing potential delays. Overall this can lead to shorter and more certain construction times, but other forms of procurement could also achieve them with effective planning and management.

The maintenance of the public infrastructure (e.g. school buildings, roads, etc.) has often been poor, and PPPs can offer some certainty that there will be adequate maintenance. This is partly as reduced maintenance of public infrastructure is often perceived as short-term 'savings', while ignoring the higher long-term costs due to the need for major, costly reconstruction later. PPPs can help reduce the risk of poor maintenance due to such shortterm public sector decisions, perhaps influenced by an election cycle, as they normally include maintaining the infrastructure at a specified level over its life. So even if budgets come under pressure elsewhere the public sector commissioner is contractually obliged to pay the PPP, so they cannot cut maintenance. However, there are alternatives, other than PPPs, for keeping required levels of maintenance, such as taking long-term contracts or ring fencing budgets for it.

\section{Flexibility or 'Lock-in'}

Circumstances and partnerships are likely to change over time, so PPPs need to respond and this may require continued trust building and adaptation to changing local or wider circumstances (Bloomfield, 2006). The lack of flexibility after a contract starts is a major problem with PPPs. For instance, if a hospital is built then it may not be easy to include changes to issues including information technology (such as better internet provision, new processes for delivering services, etc.); opportunities or requirements for changing infrastructure standards (e.g. the need for greater energy efficiency or the addition of alternative energy sources such as solar panels); or changing the way of organising work (which may require changes to the physical structure of the building), etc. Therefore, the project may suffer from being 'locked-in' to a particular technological and organisational approach for many years, or the PPP contract may need to be renegotiated - another example of the 'flexibility illusion'.

External changes may also affect the PPP. In the case of the Skye Bridge PPP, changes to European Union legislation on tax (VAT) for toll bridges forced the renegotiation of the original contract (McQuaid and Greig, 2007). An increase in tax affected the demand for the facility and therefore the income of the project and the costs of the PPP.

Financing costs 
In general the capital and financing costs of PFI-type PPPs are likely to be higher than public sector borrowings. So even with efficiency savings, PPPs may cost more than 'traditional' procurement (see above). The rate of return expected on different types of PPP projects varies (e.g. schools versus toll roads) (OECD, 2014). When estimating the rate of return expected by private sector capital, financial indicators of PPP performance, particularly Internal Rate of Returns (IRR), are often used. However, these may be misleading (HM Treasury, 2013), except where related payment streams are flat, like an annuity. Cuthbertson and Cuthbertson (2012) found this assumption of flat payment streams was rarely met, based on data on actual PFI-type PPPs, so the opportunity cost to the public sector and the potential scope for profit by the private sector were both understated - i.e. there may be a 'rate of return illusion'. They suggested that outstanding debt may be a more reliable indicator of how much the annuity type payment assumptions are bent. Hence great care is needed in estimating the actual return on PPPs.

Overall, PPPs lack transparent monitoring (often due to the 'hidden', non-transparent and non-public nature of the contracts), as well as lacking transparency in their a priori evaluation - i.e. they suffer from a 'transparency illusion'. Evaluations often include physical monitoring (e.g. the meeting of building codes or standards), but should also include multi-level financial monitoring at project, public body (such as local authority) and national levels. It is important that full information on project contracts, and the financial models used by the public sector, are publicly available (and developers told of this requirement before bids are called for).

\section{Risk sharing}

A key aspect of PFI-type PPPs is the transfer and sharing of endogenous (controlled by the partners) or exogenous (beyond control of the partners) risk between the public and private sectors, so the party that is best able to is the one to bear the risk. These may include construction, operation, inflation, technological and demand risks. Exogenous risks are usually assumed by the public sector or shared (with the private sector partner getting a premium related to their share of the risk) (see OECD, 2008).

However, there will be pressure on the public sector to stop the private partners or the project from failing or going bankrupt, especially where the project is politically or economically 'sensitive', so more of the real risk is likely to rest with the public sector leading to a 'risk of failure illusion'. The public sector may have to take back control of the operation at short notice, or find another provider or renegotiate the contact, all possibly at high cost. An example is the UK government having to be involved when a large firm, Carillion, went into liquidation early in 2018, with contracts covering many sensitive public service areas, including hospitals, maintaining Ministry of Defence housing, and school 
dinners (House of Commons, 2018; House of Commons Library, 2018; National Audit Office, 2018).

A further technological risk is that as PPPs are long-term contracts, these can tie the project to a specific type of technology, therefore reducing future flexibility (a further 'flexibility illusion). It can also make it more difficult to introduce more modern technologies, leading to potentially costly re-negotiations, unless the contracts are carefully constructed and build in necessary flexibility.

\section{Procurement process and transaction costs}

There are a number of potential problems with PPP procurement. In general, the costs of developing PPP contracts are likely to be greater than under 'traditional' procurement due to their complexity and long-term nature leading to higher transaction costs as mentioned above. These transaction costs are mostly fixed; they therefore increase the minimum efficient sizes of PPPs and favour larger organisations with their economies of scale or scope. There may be information asymmetries between the public partners (especially small local public bodies) and the private sector (particularly large experienced private firms), which can be exploited by the private partners in the contract or in negotiations on PPP projects. Over time, the public sector may also lose their expertise in the delivery of services going to PPPs and therefore suffer from further expertise and information gaps, especially in services where outputs are difficult to measure. Together these information asymmetries and varying levels of expertise can lead to an 'expertise illusion' where the public sector overestimate or fail to value their expertise.

While some of the procurement costs are transferred to the PPP in terms of the private sector bidders developing their own solutions to meet the requirements of the PPPs, the complexity of projects over their life cycles may lead to poor protection of the public interest (Da Cruz and Marques, 2012). PPPs may even lead to a reduction in protection of public resources due to over-specified procurement procedures (Verhoest et al., 2016), although the standardisation of PPP contracts can improve the procurement process (van den Hurk and Verhoest, 2016). Establishing dedicated PPP units in government (OECD, 2010) may sometimes help alleviate these problems. However, in a study of 19 European countries, van den Hurk et al. (2016) found that support agencies for PPPs varied considerably in practice (they distinguished four categories from sceptical systems of zero support to fully organised PPP systems). Also some PPP support agencies may have difficulties in assessing alternative funding models, depending on their expertise, remit and external pressures. 
The procurement of PPPs can also include systematic cognitive and social biases amongst the public sector actors commissioning PPPs and their partners, which may lead to nonrational decisions. The impacts of social and cognitive biases, as well risk preference and time biases, is an area that would benefit from further research. A few examples of relevant behavioural biases, or 'behavioural illusions' include:

- hyperbolic discounting (e.g. Laibson, 1997) resulting in a preference for immediate payoffs compared to greater longer-term pay-offs, which is a fundamental aspect of budget enlargement PPP activity;

- optimism bias (Sharot et al., 2007) may be present in many PPPs where the positives are given greater weight than potential negatives;

- anchoring biases (Tversky and Kahneman, 1974) where one characteristic of the project (e.g. the published opening date) is overly focused upon even if it negatively affects other aspects of the project (such as long-term costs);

- 'availability cascade' (Kuran and Sunstein, 1999) where a collective belief (such as the perceived efficiency of the private sector) is self-reinforced by repetition in public discourse (which arguably affected attitudes towards PFI-type PPPs for many years);

- framing effects (Tversky and Kahneman, 1981) where different decisions are made depending on whether the effects are presented as a positive rather than a cost (e.g. focusing on "the project would be opened next year and the cost per year is small" rather than "the total cost over the lifetime is higher than with other forms of delivery").

These potential biases raise a number of issues with decision-making on PFI-type PPPs. First, they illustrate that, even if there is a clear rational objective for entering a PPP, the actual decisions may not be fully rational, but rather subject to many behavioural biases, influences or 'behavioural illusions', hence perhaps only giving the 'illusion' of decisions being 'hard-nosed' or fully rational. Second, decisions are made in a wider societal, economic and institutional context, so focusing only on the decision process of the individual organisation or person ignores the influences of other actors (personal as well as professional) on that decision. So we should not consider the decision makers as individual atoms, but rather molecules of tightly linked relationships within a wider compound or solution of loosely linked, for example, institutional and socio-economic relationships. Behavioural analysis hence, could benefit from being more integrated with relationship perspectives and forms of analysis, such as social network analysis. Third, there may be different objectives, or rationalities for decisions, underlying a PPP actor's decisions, for instance a firm entering a PPP may be influenced not just by commercial logics or motivations, but also other social factors. Similarly, different stakeholders (public and 
community ones for example, as well as private sector stakeholders) may have various combinations of motivations and rationalities for their decisions, and these may change over time.

One way of widening perspectives on thinking about PPPs before they are commissioned is to have greater involvement of the public and future users of the services. Boyer et al. (2016) argue that, empirically, public involvement can improve the wider support for PPPs and the adaptation of project design to local conditions. However, generally the public participation processes do not appear to have much influence on the delivery of the project or imbalances of power between public and private sectors.

\section{Legacy and public assets}

The legacy after a PPP ends, as well the operation of the PPP, should be considered. As public sector officials are often not directly involved in providing a service within a PPP, PPPs may reduce the public sector's ability to learn the lessons from providing the service. This may affect the development of future policy, and their ability to learn from past experience, therefore leading to possible repetitions of previous mistakes due to a lack of corporate 'memory'. Local community, public and SME knowledge may also be lost if large external firms develop and deliver most of the PPP. Therefore, mechanisms are needed to ensure that such knowledge continues to be accessible to the relevant public sector bodies and others to avoid a 'legacy illusion' where future implications of PPP decisions are not adequately considered.

The issue of the handing over a service or building after the end of the PPP is important. If a contract states that the infrastructure is handed back to the public sector at the same standard after 30 years, it is important to explicitly state if this handing over is to be at the original building standards (e.g. in terms of energy efficiency, structural standards, IT, etc.) or at the standards current at the date when handed over. If the former then what is being handed over may be a totally out of date structure or service.

\section{Wider impacts of PPP on the local economy}

PPPs may assist in developing the capabilities of SMEs and larger firms in the local private sector, as they learn from joint ventures with larger national or international firms, as well as promote regional innovation (Kristensen et al., 2014). Potential also exists for gaining subcontracts (e.g. services provision or facilities management). However, most PPPs are large, especially when projects are 'bundled' together in a package. Therefore, only lower level contracts or service provision may be available to smaller local companies and they may 
have to deal with PPP main contractors who maintain considerable market power, limiting technology transfer and restricting development - resulting from a 'big is beautiful illusion'.

In addition, negative impacts can affect the public good as a consequence of reducing the risks for a PPP. For instance, where the public sector agrees not to build or improve potentially competing roads near a PPP toll road (Plewik, 2000), this can lead to a degree of monopoly power for the PPP and hinder future economic development of the region.

\section{Services PPP, a series of balances}

In addition to the many factors discussed above, when delivering services a decision maker needs to balance a series of factors in order to choose whether or not to use PFI-type PPPs, and if so what type of PPP to use. Some of these balances (in addition to factors such as risk, cost, specifications etc.) are now illustrated. These include:

Quality of services (which are usually hard to measure) versus efficiencies (which are often an issue for Government and users given increasing demographic and other demands on their resources). Care must be taken to avoid a 'quality illusion' where the quality is assumed to be as good as or better than before, but without adequate in-depth monitoring.

Efficiencies may be achieved by cutting wages and conditions of workers (sometimes due to reduced Trades Unions influence or other weakening in employee bargaining positions), which gives an 'illusion of efficiency' rather than comparing genuine productivity due to reducing salaries or other costs rather than increasing output per hour or quality etc.

Economies of scale and scope versus diseconomies scale (e.g. if provision is less responsive to local demand due to corporate policies of the private operators or public commissioning agency) - an 'economies of scale illusion'.

Innovation versus restricted innovation and competition due to monopoly or oligopoly power (if there is limited genuine competition, due for instance to minimum PPP size conditions preventing smaller competition) - a 'competition illusion'.

Roles of service users and local communities in the development, which will be important for the appropriate operation of the services and the social sustainability of the project versus control by the main PPP funders and operators. Care needs to be taken to avoid token involvement of these stakeholders in major decisions and the on-going operation of the PPP - an 'involvement illusion'. 
Hence, there is no definitive type of PPP when considering a services based PFI-type PPP. Rather the decisions should be made on a clear and transparent long-term basis which includes the perspectives of the full range of stakeholders and which includes the socioeconomic impacts and distributional and equity issues associated with using PPPs and with different forms of PPPs or other forms of service provision.

\section{Summary of 'illusions' related to rational choices in PPPs}

This paper has set out some of the major factors that are important when considering the use of contract based, PFI-type PPPs. There are many arguments in favour of well-designed PPPs. However, when making decisions on PPPs great care must be taken to avoid a number of issues whereby the choices give the 'illusion' being rational, but are instead affected by other factors that are not explicit or transparent. Some of these 'illusions of rational' PPP decisions are shown in Table 1, divided into the broad, overlapping areas of development and operation factors, decision-making and long-term impacts.

In total, 15 illustrative potential 'illusions' that may affect PPP decisions are as follows:

Development and operation 'illusions'

'Fiscal illusion' where the efficiency gains from PPPs do not compensate for the extra financial, transaction and other costs that they incur; or budget enlargment.

'Rate of return illusion' where the rate of return calculation is inappropriate, (e.g. the use of Internal Rate of Returns (IRR) may be misleading, where related payment streams are not flat).

'Risk of failure illusion' where the distribution of the full risks are not explicitly recognised, (e.g. a PPP is prevented from going bankrupt or is replaced by additional public funding, as the service is essential or 'politically sensitive').

'Flexibility illusion' where PPPs restrict future choices (e.g. closing non-PPP schools rather than PPP ones, as costs of the latter must continue to be paid rather than deciding on the basis of need; or 'lock-in' to a particular technological and organisational approach due to the introduction of new technology not in the original PPP contract etc.). 
'Quality illusion' where the quality (especially of social services PPPs) is assumed to be as good as or better than before, but without adequate in-depth evidence or monitoring.

'Efficiency illusion' where apparent increases in efficiency are mainly due to, for example, lower pay and conditions of staff and not due to greater quality and/or output per hour.

'Competition illusion' where limited real competition results in monopoly or oligopoly power for PPP bidders and contractors.

'Economies of scale illusion' where diseconomies of scale are ignored and only the positive economies of scale or scope are considered.

\section{Decision-making 'illusions'}

'Evaluation illusion' where ex-post evaluations are not rigorous or robust enough to give accurate findings. Also in a prori evaluations where the comparators for the PPP are artificially constrained (e.g. by not including the best reasonable or practical alternative).

'Transparency illusion' where there is a lack of public transparency about information on the procurement and on-going monitoring of the PPP, so making it impossible to fully judge their effectiveness and efficiency.

'Expertise illusion' where the public PPP procurement agencies lack sufficient expertise, or have inadequate information, compared to the other PPP partners with whom they are negotiating.

'Behavioural illusions' where systematic cognitive and social biases amongst those commissioning PPPs and their partners, lead to non-rational decisions, (e.g. those identified in behavioural science such as social and cognitive biases, risk preference and time biases).

Long-term impact 'illusions'

'Legacy illusion' where inadequate consideration is given to the indirect, long-term implications of transferring functions to PPPs, (e.g. there may be a loss of institutional memory or expertise in the commissioning bodies and where future increases in standards of infrastructure or service provision are not fully incorporated in the PPP). 
'Big is beautiful illusion' where the full, long-term effects on SMEs and the local economy of using large PPP contractors are not fully taken into account.

'Involvement illusion' where key stakeholders, such as service users and local communities, are given no or only token involvement in major decisions on the development and on-going operation of the PPP, so there is a lack of meaningful input from them.

Of course, many of these influences or negative effects can be minimised, but not entirely removed, by well-constructed PPP contracts.

\section{Conclusions}

This paper has illustrated that decisions about the development and operation of PPPs can be affected by factors that are not explicitly or transparently considered, hence sometimes giving the decision an 'illusion' of being rational. The paper set out a series of such potential 'illusions' that should be clearly taken into account when considering the use or choice of PPPs. Some fifteen of these 'illusions of rational' PPP decisions were considered and divided into the broad, overlapping groups related to development and operation factors, decisionmaking and long-term impacts. Removing such 'illusions' may make some PPPs less attractive, from an economic and perhaps political perspective, but result in improvements for those that are agreed.

PPPs are significantly influenced by the socio-economic, legal, legislative and financial system they are embedded in. Hence a clear process for approving projects and recognising all the costs and benefits of a PPP is needed, including developing criteria and instruments to measure each phase of a PPP and its overall value added to the economy and society over its lifetime. A clear a priori and on-going evaluation process for deciding on PPPs needs to be used and alternatives fully compared, so as to identify the option most appropriate and offering best value for money over the entire lifespan of the infrastructure or service. Greater consideration should be given to significantly improving PPP procurement processes, and also to alternative forms of financing and developing projects, including 'traditional' methods. Despite the potential problems of PFI-type PPPs, they may be worthwhile if properly assessed and managed. In addition other forms of PPP will remain crucial for innovative, efficient and efficient public service delivery.

All PPPs and their evaluation processes should be transparently and rigorously monitored at project, public agency, regional and national levels. This should be public and transparent, 
as there is large scope for excessive profits or use of monopoly power where there is limited effective competition among providers. If PPPs are chosen as the most effective and efficient method for a project, then it is essential that there is expertise to support for the procurer of the infrastructure and/or services both nationally and at regional/local levels and in specific industrial sectors. The relevant stakeholders, including the local communities and service users, should also be fully involved at all stages of a PPP development and operation.

Full transparency, having suitable support and explicitly taking account of potential 'illusions' affecting apparent rational decisions could lead to different decisions, including the decision not to progress the project or to use alternative funding and development methods. This is also important when attempting to achieve genuine innovation and the effective and efficient provision of infrastructure and services through PFI-type PPPs or by other methods.

Finally, research is needed into the socio-political-economic factors underlying the rise of PFI-type PPPs and how they were influenced by political factors, including governments wishing to spend today and tax tomorrow, economic considerations, and other factors such as lobbying by financial and other vested interests. In summary, while there are potential advantages of PFI-type PPPs in some cases, it is crucial that previous mistakes are avoided and that a transparent and robust system of support is available to those considering or evaluating the use of PPPs, and that alternatives are fairly considered. It remains to be seen what new types of PPPs might be consistent with long-term efficient, effective and accountable services and infrastructure provision in an era of pressure on resources and high service demands.

\section{Acknowledgements}

The author would like to thank anonymous referees for their very useful comments and the Asia Development Bank Institute for supporting earlier research on PPPs. All errors remain the responsibility of the author.

\section{References}

Barlow, J., Roehrich, J. and Wright, S. (2013): Managing Health Care Facilities and Services Europe sees Mixed Results from Public-Private Partnerships for Building and Services, Health Affairs, Vol. 32, No. 1, pp.146-154. 
Bloomfield, P. (2006): The challenging business of long-term public-private partnerships: reflections on local, Public Administrative Review, Vol. 66, No. 3, pp.400-11.

Boyer, E.J., Van Slyke, D.M. and Rogers, J.D. (2016): An Empirical Examination of Public Involvement in Public-Private Partnerships: Qualifying the Benefits of Public Involvement in PPPs, Journal of Public Administration Research and Theory, Vol. 26, No. 1, pp.45-61.

Bifulco, L. (2016): Social Policies and Public Action. London: Routledge.

Bull, B. (2010): Public-Private Partnerships: the United Nations Experience, in Hodge, G. Greve, C. and Boardman, A. (Eds): International Handbook on Public-Private Partnerships, Cheltenham: Edward Elgar, pp.479-498.

Cuthbertson, J.R. and Cuthbertson, M. (2012): Why IRR is an inadequate indicator of costs and returns in relation to PFI schemes, Critical Perspectives on Accounting, Vol 23, No. 6 , pp.420-433.

Da Cruz, N.F. and Marques, R.C. (2012): Mixed companies and local governance: no man can serve two masters, Public Administration 90, No. 3: 737-758.

Dunleavy, P., Margetts, H., Bastow, S. and Tinkler, J. (2006): Digital era governance: IT corporations, the state and e-government, Oxford: Oxford University Press.

Eisenführ, F., Weber, M., and Langer, T. (2010): Rational decision making, Heidelberg: Springer.

EPEC (The European PPP Expertise Centre) (2018): Market Update: Review of the European PPP Market in 2017. Brussels: EPEC.

European Commission (2004): Green Paper on public-private partnerships and Community law on public contracts and concessions [COM2004. 327 final]. Brussels: CEC.

European Commission (2012): New public-private partnerships for research in the manufacturing, construction and automotive sectors: European PPP research supports economic recovery; Progress Report, Directorate-General for Research and Innovation, Unit G2 "New Forms of Production". Luxembourg: Publication Office of the European Union.

Financial Reporting Advisory Board (FRAB) (2007): Accounting for PPP Arrangements including PFI Contracts, 10 December 2007. London: TSO.

Geddes, R. Richard \& Wagner, Benjamin L., (2013): Why do U.S. states adopt public-private partnership enabling legislation?, Journal of Urban Economics, Vol. 78(C), pp. 30-41.

HM Treasury (2000): Public Private Partnerships: the Government's Approach. London: GSO.

HM Treasury (2008): Infrastructure Procurement: Delivering Long-Term Value, March. London: HM Treasury.

HM Treasury (2012): A new approach to public private partnerships. London: HM Treasury. Available at:

https://www.gov.uk/government/uploads/system/uploads/attachment data/file/205112/pf2 infrastructure new approach to public private parnerships 051212.pdf.

HM Treasury (2013): Guidance Note: the use of internal rates of return in PFI projects. London: HM Treasury. Available at:

https://www.gov.uk/government/uploads/system/uploads/attachment data/file/225363/02 pfi internalratesguidance1 210307.pdf.

HM Treasury (2016a): National Infrastructure Delivery Plan 2016-2021. London: HM Treasury. Available at: https://www.gov.uk/government/uploads/system/uploads/attachment data/file/520086/29 04569 nidp deliveryplan.pdf. 
HM Treasury (2016b): Private Finance Initiative and Private Finance 2 projects: 2015 summary data. London: HM. Treasury.

Hodge, G.A. and Greve, C. (2007): Public-Private Partnerships: an international performance review, Public Administration Review, Vol. 67, No. 3, pp.545-558.

Hodge, G. and Greve, C. (2013): Public-private partnerships in turbulent times, in Greve, C. and Hodge, G. (Eds): Rethinking Public-Private Partnerships. London and New York: Routledge, pp.1-32.

Hoppe, E.I. Kunsterer, D.J. and Schmitz, P.W. (2010): Public-private partnerships versus traditional procurement: Innovation incentives and information gathering. CEPR Discussion Paper 7681. London: CEPR.

House of Common Treasury Committee (2011): Private Finance Initiative, Seventeenth Report of Session 2010-2012, HC 1146, July 2011, paragraph 48.

House of Commons, Committee of Public Accounts (2011): Lessons from PFI and other projects, Forty-fourth Report of Session 2010-12, HC1201. London: Stationery Office. Available at: http://www.publications.parliament.uk/pa/cm201012/cmselect/cmpubacc/1201/120102.ht $\underline{\mathrm{m}}$.

House of Commons (2018): Carillion former directors questioned on collapse, The Work and Pensions and Business, Energy and Industrial Strategy Committees, https://www.parliament.uk/business/committees/committees-a-z/commons-select/workand-pensions-committee/news-parliament-2017/carillion-directors-17-19/.

House of Commons Library (2018): The collapse of Carillion, Briefing Paper No. 08206. London: House of Commons. Available at: http://researchbriefings.files.parliament.uk/documents/CBP-8206/CBP-8206.pdf.

House of Lords (2010): Private Finance Projects and off balance sheet debt, HL Paper 63-I. London: The Stationery Office.

Inderst, G. (2016): Infrastructure Investment, Private Finance, and Institutional Investors: Asia from a Global Perspective. ADBI Working Paper 555. Tokyo: Asian Development Bank Institute. Available at: http://www.adb.org/publications/infrastructure-investmentprivate-finance-and-institutional-investors-asia-global/.

ILO (International Labour Organisation) (2008): Private Public Partnerships. GB.301/TC/1. Geneva: ILO.

IoB (2013): Public-Private Partnerships in developing countries - A systematic literature review, Ministry of Foreign Affairs, The Netherlands, Amsterdam.

Kristensen, I. McQuaid, R. and Scherrer, W. (2014): Regional Innovation Policy and PublicPrivate Partnerships, in Hilpert, U. (Ed.): Handbook on Politics and Technology. London: Routledge, pp. 249-261.

Kuran, T. and Sunstein, C.R. (1999): Availability cascades and risk regulation. Stanford Law Review, Vol. 51, No. 4, pp.683-768.

Laibson, D. (1997): Golden eggs and hyperbolic discounting, The Quarterly Journal of Economics, Vol. 112, No. 2, pp.443-478.

Malone, N. (2005): The Evolution of Private Financing of Government Infrastructure in Australia-2005 and Beyond, Australian Economic Review, Vol. 38, No. 4, pp.420-430.

Martin, L., Lawther, W., Hodge, G. and Greve, C. (2013): Internationally Recommended Best Practices in Transportation Financing Public-Private Partnerships (P3s), Public Administration Research, Vol. 2, No. 2, pp. 15-25. 
McQuaid, R.W. (2000): 'The Theory of Partnerships - Why have Partnerships', in S.P. Osborne (ed.): Managing public-private partnerships for public services: an international perspective (Routledge, London) pp. 9-35.

McQuaid, R. (2010): Theory of Organisational Partnerships - partnership advantages, disadvantages and success factors, in Osborne, S.P. (ed.) The New Public Governance: Emerging perspectives on the theory and practice of public governance. London: Routledge, pp.125-146.

McQuaid, R. (2018): 'Contract-type Public Private Partnerships in Services', in Ahmed, A. (ed.) World Sustainable Development Outlook 2018 - Public Private Partnerships for the Implementation of the 2030 Agenda for Sustainable Development. London: World Association for Sustainable Development, pp. 33-47.

McQuaid, R.W. and M. Greig (2007): The Bridge to Skye, Scotland, in: Baldacchino, G. (Ed.): Bridging Islands: The Impact of Fixed Links. PEI, Canada: Acorn Press, pp. 185-202

McQuaid, R.W. and Scherrer, W. (2010): Changing reasons for public private partnerships (PPPs), Public Money and Management, Vol. 30, No. 1, pp.27-34.

National Audit Office (2009): Private Finance Projects, Paper for the Lords Economic Affairs Committee. London: House of Lords.

National Audit Office (2018): PFI and PF2, HC 718 SESSION 2017-2019, 18 January 2018. London: NAO. Available at: https://www.nao.org.uk/wp-content/uploads/2018/01/PFI-andPF2.pdf.

NHS (National Health Service Executive) (2004): Public Private Partnerships in the National Health Service: The Private Finance Initiative Good Practice, Treasury Taskforce, London.

OECD (Organisation for Economic Development and Co-operation) (2008): Public-Private Partnerships: In Pursuit of Risk Sharing and Value for Money. OECD: Paris.

OECD (2011): Regions and Innovation Policy, OECD Reviews of Regional Innovation. OECD: Paris.

OECD (2012a): OECD Principles for the Public Governance of Public-Private Partnerships. OECD: Paris.

OECD (2012b): Policy Framework for Investment. OECD: Paris.

OECD (2014): Pooling of Institutional Investors Capital. Selected Case Studies in Unlisted Equity Infrastructure. OECD: Paris

Osei-Kyei, R., Chan. A.P.C., Javed, A.A.and Ameyaw, E.F. (2017): Critical success criteria for public-private partnership projects: international experts' opinion, International Journal of Strategic Property Management, Vol. 21, No. 1, pp. 87-100.

Plewik, M. (2000): Public-Private Partnership: Toll Motorways Construction in Poland, in Montanheiro, L. and Linehan, M. (Eds): Public and Private Sector Partnerships: The Enabling mix. Sheffield, Sheffield Hallam University Press, pp.499-506.

Pollock, A.M., Price, D. and Player, S. (2007): An examination of the UK Treasury's evidence base for cost and time overrun data in UK value-for-money policy and appraisal, Public Money and Management, Vol. 27, No. 8, pp.127-134.

Pollock, A.M. and Price, D. (2013): PFI and the National Health Service in England. Available at: http://www.allysonpollock.com/wpcontent/uploads/2013/09/AP 2013 Pollock PFILewisham.pdf.

Reynaers, A.-M. and Grimmelikhuijsen, S. (2015): Transparency in Public-Private Partnerships: Not So Bad After All? Public Administration, Vol. 93, No. 3, pp.609-626. 
Sharot, T., Riccardi, A.M., Raio, C.M. and Phelps, E.A. (2007): Neural mechanisms mediating optimism bias. Nature, Vol. 450, No. 7166, pp.102-105.

Thieriot, H. with Dominguez, C.C. (2015): Public-Private Partnerships in China, On 2014 as a landmark year, with past and future challenges, Discussion Paper, IISD, Winnipeg, Canada, April 2015. Available at: https://www.iisd.org/sites/default/files/publications/public-private-partnerships-china.pdf.

Torchia, M., Calabrò, A. and Morner, M. (2015): Public-Private Partnerships in the Health Care Sector: A systematic review of the literature, Public Management Review, Vol. 17, No. 2, pp.236-261.

Tversky, A. and Kahneman, D. (1974): Judgment under uncertainty: Heuristics and biases, Science, Vol. 185, No. 4157, pp.1124-1131.

Tversky, A. and Kahneman, D. (1981): The framing of decisions and the psychology of choice, Science, Vol. 211, No. 4481, pp.453-458.

UN (United Nations) (2001): Cooperation between the United Nations and all relevant partners, in particular the private sector, UN, New York http://www.un.org/partnerships/Docs/partnershipreport a-56-323.pdf.

UN (2011): A Guidebook on public-private partnership in Infrastructure. Bangkok: Economic and Social Commission for Asia and the Pacific.

United Nations UN PPPKnowledgelab (No date): Country-level PPP Profiles. Available at: https://pppknowledgelab.org/countries.

UNECE (United Nations Economic Commission for Europe) (2008): Guidebook on Promoting Good Governance in Public-Private Partnerships, UNECE, Geneva. Available at: http://www.unece.org/fileadmin/DAM/ceci/publications/ppp.pdf.

UNECE (2012): Report of the Team of Specialists on Public-Private Partnerships. Geneva: The Committee. Available at: http://www.unece.org/fileadmin/DAM/ceci/Latest Documents/ECE CECI PPP 2012 2.p df.

Van den Hurk, M. and Verhoest, K. (2016): The challenge of using standard contracts in public-private partnerships, Public Management Review, Vol. 18, No. 2, pp.278-299.

Van den Hurk, M., Brogaard, L., Lember, V., Petersen, O.H. and Witz, P. (2016): National varieties of Public-Private Partnerships (PPPs): A comparative analysis of PPPsupporting units in 19 European countries, Journal of Comparative Policy Analysis, Vol. 18, No. 1, pp.1-20.

Verhoest, K., Van Garsse, S., van den Hurk, M. and Willems, T. (2016): 'Developments of public private partnership in Belgium', in Akintoye, A., Beck, M. and Kumaraswamy, M.M. (eds), Public-private partnerships: A global review 45-58.

World Bank (2009): About Public-private partnership in infrastructure. Washington: World Bank.

World Bank (2014): World Bank private participation in infrastructure database. Available at: http://ppi.worldbank.org/

World Bank (2015): PPP Arrangements / Types of Public-Private Partnership Agreements. Washington: World Bank. Available at: http://ppp.worldbank.org/public-privatepartnership/agreements 